\title{
1. Introduction: regulation of biotechnology, between anxieties and trust in scientific progress
}

\section{MODERN BIOTECHNOLOGY FROM AN INTERNATIONAL REGULATORY PERSPECTIVE}

Since time immemorial mankind has resorted to breeding techniques to achieve new characteristics in plants or animals or used microorganisms to produce food. In the last decades, genetic engineering catalysed scientific and technological progress in biomedicine, agriculture and other fields. Genetic engineering accelerated the selection and creation of animals, plants and microorganisms with desired traits. Reproduction techniques like in vitro fertilization (IVF) allow unfulfilled wishes to have children to be satisfied, diagnostic methods on very early stages of human life to be practised and human stem cells to be produced. Other forms of reproduction such as human cloning are most controversial and widely banned.

More recently, genome editing (CRISPR/Cas) and synthetic biotechnology have opened new paths for modifying the genome without transferring DNA from other organisms, for treating diseases and creating new varieties of plants. The method of genome editing seems to open new perspectives which might revolutionize biotechnology by virtue of its unprecedented precision. In comparison with established methods of genetic engineering, analysts equate this new technique with a scalpel as opposed to sledgehammers. ${ }^{1}$

Genome editing ${ }^{2}$ can be described as a three-step procedure: a probe locates the relevant genes. Then a 'molecular scissor' (e.g. the Cas9-protein) can cut

1 The comparison was made by J. Doudna, cf. K. Loria, 'The genetic technology that's going to change everything is at a critical turning point' (11 August 2015) Business Insider [available online] http://www.businessinsider.com/how-crispr-could -change-the-world-2015-8.

2 European Commission, New Techniques in Agricultural Biotechnology, Scientific Advice Mechanism, Explanatory Note 02/2017 (28 April 2017) [available online] http://ec.europa.eu/research/sam/pdf/topics/explanatory_note_new_techniques _agricultural_biotechnology.pdf, pp. 56 et seq. 
the DNA. The modification builds on the DNA repair mechanisms of the target cell. In the re-joining process DNA building stones can be deleted, changed or inserted. This can result in the elimination of gene functions. ${ }^{3}$ While traditional genetic engineering is associated with a relatively high degree of inaccuracy, genome editing allows insertions to be targeted, thus considerably reducing unintended effects on the expression of genes or their disruption. ${ }^{4}$ This method provides the ability to realize point mutations (a single nucleotide base substitution, insertion or deletion which can entail an important phenotypic change) and to make other narrowly defined modifications..$^{5}$ The high accuracy of genome editing also saves costs and time. Bioethicist Henry Greely compares CRISPR/Cas9 to the Model T Ford:

The Model T was not the first car, and it was not the last car, but it was ... the inflection point. Cars went from being the expensive, unreliable province of the curious rich to something anyone could, and soon did, own. With CRISPR/Cas9, and its inevitable descendants, genome editing will become similarly widely available and widely used - 'democratized'. ${ }^{6}$

In 2015 CRISPR/Cas9 was elected 'Breakthrough of the Year' by Science magazine. ${ }^{7}$ In 2016 the Danish Council of Ethics adopted a Statement on Genetic Modification of Future Humans. The Recommendation on the alteration of fertilized eggs and germ cells with the intention of removing susceptibility to disease in future children and their offspring reflects conflicting views within the Council:

Gene-based therapy should not be offered until the technologies are far more developed and safety tested than the case is today, and there are major technical problems to overcome before this will be the case. Some of the Council members are sceptical that it will ever be possible to gain the knowledge required to ensure the development of adequately safe treatments, and they therefore also question the value of researching and developing such initiatives. However, if safe removal of susceptibility to disease from germ cells or fertilised eggs should become possible,

3 D. Carroll and R. Alta Charo, 'The Societal Opportunities and Challenges of Genome Editing’ (2015) 16 Genome Biology 242.

4 European Commission, New Techniques in Agricultural Biotechnology, Scientific Advice Mechanism, Explanatory Note 02/2017 (28 April 2017) [available online] http://ec.europa.eu/research/sam/pdf/topics/explanatory_note_new_techniques _agricultural_biotechnology.pdf, p. 18.

5 ibid.

6 H.T. Greely, Are We Ready for Genetically Modified Animals? World Economic Forum Global Agenda (19 January 2016) [available online] https://www.weforum.org/ agenda/2016/01/are-we-ready-for-genetically-modified-animals/.

7 J. Travis, 'Making the Cut' (2015) 350 Science 1456. 
it will be necessary to consider if such interventions should be allowed in Denmark. Research has developed beyond our imagination before, giving us results that no one would have believed possible - recall Dolly the sheep cloned from a cell from its mother's udder. It is therefore relevant to consider these future scenarios regardless of the fact that we may point to many and considerable obstacles standing in the way of realisation. ${ }^{8}$

Synthetic biology combines a number of modern techniques from biotechnology, computer science and other areas to engineer new organisms which do not exist naturally. ${ }^{9}$ Synthetic biology allows entire genomes to be redesigned and synthesized. In 2010, scientists at the J. Craig Venter Institute created the first living organism with a synthetic genome. They transplanted a chemically synthesized genome (a modified genome of bacterium Mycoplasma mycoides, which occurs naturally) to cells of another bacterium Mycoplasma capricolum; in this process the original genome of the target organism was destroyed.

All these biotechnological developments confront international, national and European Union law with a wide array of regulatory issues: the protection of health and the environment including biodiversity, therapeutic and diagnostic options, the response to risks in the light of scientific uncertainty, human rights, the response to societal and ethical concerns, labelling and consumer protection, restrictions of international trade, intellectual property, access to genetic resources and the coexistence of genetically modified crops and conventional or ecological agriculture.

Many human rights treaties and environmental and trade agreements, as well as many other non-binding international instruments, deal with these issues. A number of them specifically address modern biotechnology and its implications, such as the European Convention on Biomedicine and Human Rights or UNESCO's Universal Declaration on the Human Genome and Human Rights. Some treaties with a broader scope contain clauses which cover particular aspects of biotechnology. Thus, Article 8(g) of the UN Convention on Biodiversity calls upon each contracting party to

establish or maintain means to regulate, manage or control the risks associated with the use and release of living modified organisms resulting from biotechnology

8 Danish Council of Ethics, 'Statement from the Danish Council of Ethics on Genetic Modification of Future Humans in Response to Advances in the CRISPR Technology - adopted in 2016' (2017) 22 Jahrbuch für Wissenschaft und Ethik 269, 280.

9 European Commission, New Techniques in Agricultural Biotechnology, Scientific Advice Mechanism, Explanatory Note 02/2017 (28 April 2017) [available online] http://ec.europa.eu/research/sam/pdf/topics/explanatory_note_new_techniques _agricultural_biotechnology.pdf, pp. 71 et seq. 
which are likely to have adverse environmental impacts that could affect the conservation and sustainable use of biological diversity, taking also into account the risks to human health.

Building on this provision, the Cartagena Protocol on Biosafety establishes a legal regime for the cross-border transport of and trade with living genetically modified organisms.

Numerous agreements cover modern reproduction techniques, other applications of biotechnology or biotechnological products which are being confined to biotechnological issues. Human rights treaties with a general scope allow or restrict techniques of human reproduction. The law of the World Trade Organization (WTO) and many other trade agreements govern the import of genetically engineered products and biotechnological inventions.

Many concerns which are widespread in the countries of the European Union find little echo even in other Western societies. Socio-cultural differences are translated into different regulatory approaches which are often visible in regional agreements or other regional instruments. Some universal or regional treaties bridge such disparity gaps with indeterminate or flexible clauses which leave room for divergent political options. Others, like some agreements of the WTO, require a scientifically sound justification for regulatory impediments.

In some areas there is an emerging global consensus. Reproductive human cloning, or eugenic practices or obligatory genetic tests are widely rejected as unethical and banned in agreements and non-binding international instruments as well. They are also prohibited in many national jurisdictions.

A crucial factor in the regulation of modern biotechnology is the response to uncertainty in the light of available knowledge. It is often difficult to anticipate and assess the long-term consequences of new products and new technologies. For a considerable period of time, the precautionary principle has served as a fundamental standard of risk management in international environmental law. This principle allows regulatory measures against potentially harmful activities or products even if a causal link is not reliably established. While risk assessment builds on available scientific information, the following risk management flows from a political choice based on the likely benefits of a technology, the availability and costs of preventive measures as well as the relative weight of the assessed risk in relation to the benefits and to controlling measures. Regulatory choices as to new technologies range from a 'liberal' or indifferent abstention from regulatory intervention to irrational scepticism and restrictions without any scientific risk assessment.

Risk assessment and risk management play an important role in international trade law. Regulatory restraints on imports of biotechnological products operate as barriers to trade, which call for a justification. The General Agreement on Tariffs and Trade (GATT) and the Agreement on Sanitary and 
Phytosanitary Measures (SPS Agreement) follow an essentially science-based approach to risk management. The Agreement on Trade-Related Aspects of Intellectual Property Rights (TRIPS Agreement), in principle, requires the patentability of biotechnological inventions. In this context, it is often difficult to draw the line between an inventive step and mere discoveries, e.g. as to patents on human gene sequences.

It is a major challenge for international law in the field of biotechnology to balance the objective of a coherent international regulation with deference to diverse socio-economic perceptions and various legal cultures. International standards should leave enough space and discourse in our societies rather than pre-empt all political choices.

\section{OPPORTUNITIES AND RISKS OF BIOTECHNOLOGY}

Douglas McCormick in 1996 found that '[t]here is no such thing as biotechnology, there are biotechnologies' ${ }^{10}$ In this regard, this chapter discusses opportunities and risks distinguishing the different fields of 'green', 'red' and 'white' biotechnology.

\subsection{Biotechnology and agriculture ('green' biotechnology)}

'Green' biotechnology is the application of biotechnological methods to improve the quality of agricultural products or increase yields. ${ }^{11}$ Mankind has laboured to enhance the productivity, nutritional value or taste of plants ever since the Neolithic period. About $20 \mathrm{~km}^{2}$ were needed to feed one hunter and gatherer. Today, the same area can provide food for 9,000 persons. ${ }^{12}$ Man started cultivating plants and domesticating animals about 11,000 years ago, a process which allowed him to change from a migratory life to permanent settlements. ${ }^{13}$ Classic breeding relies on the selection of plants with desired traits. Systematic selection breeding and the discovery of the laws of genetics sped

10 D.K. McCormick, 'First Words, Last Words' (1996) 14 Bio/Technology 224.

11 European Commission, New Techniques in Agricultural Biotechnology, Scientific Advice Mechanism, Explanatory Note 02/2017 (28 April 2017) [available online] http://ec.europa.eu/research/sam/pdf/topics/explanatory_note_new_techniques _agricultural_biotechnology.pdf.

${ }_{12}$ Deutsche Forschungsgemeinschaft, Grüne Gentechnik (DFG/Wiley, Bonn 2011) [available online] http://www.dfg.de/download/pdf/dfg_magazin/forschungspolitik/ gruene_gentechnik/broschuere_gruene_gentechnik.pdf, p. 9.

13 R. Schmid and C. Schmidt-Dannert, Biotechnology: An Illustrated Primer (Wiley-VCH, Weinheim 2016) 274; J.E. Smith, Biotechnology (CUP, Cambridge 2009) 3 . 
up this hitherto lengthy breeding process in the 19th century. Up to the middle of the 20th century, the variety of characteristics to be selected was confined to naturally existing features. New methods of producing hybrids, mutation by irradiation or the use of chemicals (mutagenesis) since the 1950s considerably increased genetic variety as a basis for the selection process. ${ }^{14}$

Since the 1980s, genetic engineering has been widely used to transfer genetic material even to unrelated organisms. ${ }^{15}$ It allows for the transfer of a gene of one species to another, e.g. to enhance resistance to pests, pesticides, cold or draughts. The transfer of genes from other organisms may be realized by linking the DNA to small particles to be bombarded towards the target cell ('gene gun') or, more commonly, by using agrobacteria as a vehicle. ${ }^{16}$ It is not reliably foreseeable where the transgene will be incorporated in the target cell. In light of this inaccuracy, the desired results usually require a multitude of tests. Modern techniques of genome editing open new perspectives for agriculture. The identification of a gene which controls the ability of plants to absorb nitrogen may allow the creation of varieties of rice, wheat and other crops, which promise high yields with a dramatic reduction of fertilizers. ${ }^{17}$ British and Chinese researchers discovered that the GRF4 gene encodes a protein that restrains the effects of the DELLA protein, which is responsible for poor nitrogen absorption. ${ }^{18}$ Some researchers hail this perspective as a breakthrough in sustainable farming and a new 'green revolution'. ${ }^{19}$ Marker-assisted breeding techniques facilitate the selection process. ${ }^{20}$ Molecular-genetic markers are linked to the genetic feature which is responsible for the desired characteristic and make it visible. It allows breeders to identify the cells or organisms which adopted the desired genes.

Green biotechnology can assist and speed up conventional breeding programmes. Transgenic plants can be engineered to be resistant to viruses, fungi, bacteria, herbicides or insecticides, to improve crop yield, to increase the nutritional value of food and to reduce toxic chemicals. ${ }^{21}$ Thus, Bt maize produces its own insecticide which makes it resistant to the European corn borer.

\footnotetext{
ibid., 135.

ibid., 4.

ibid., 39-40.

17 'Green revolution crops bred to slash fertilizer use' (15 August 2015) [available

online] https://www.nature.com/articles/d41586-018-05980-7.

20 E.S. Sachs, 'Biotechnology in Crop Production' in: J.S. Popp, M.M. Jahn, M.D. Matlock and N.P. Kemper (eds), The Role of Biotechnology in a Sustainable Food Supply (CUP, Cambridge 2012) 49, 57.

${ }_{21}$ FAO, Agricultural Biotechnology - Meeting the Needs of the Poor (17 May 2004) [available online] http://www.fao.org/newsroom/en/focus/2004/41655/index
}

18 ibid.

19 ibid. 
For this purpose, the gene encoding for the production of a certain insecticidal protein of the bacterium Bacillus thuringiensis (Bt) was transferred to the maize plants. ${ }^{22}$ The extensive use of Bt maize resulted in an area-wide suppression of the corn borer in the United States, which also benefits conventional maize production. ${ }^{23}$ In 2015 the US Food and Drug Administration (FDA), for the first time, approved a genetically modified animal for commercial food production: ${ }^{24}$ a GM salmon which grows twice as fast as the natural Atlantic salmon. ${ }^{25}$

A variation of established genetic engineering are techniques which insert genetic material from the same or sexually compatible species (cisgenesis and intragenesis). ${ }^{26}$ In the case of cisgenesis, the entire gene with its own regulatory elements is inserted, while the method of intragenesis introduces a new combination of regulatory or coding DNA fragments from the species itself or from a cross-compatible species.

An important and controversial example of genetic engineering applied with the objective to fight malnutrition is 'golden rice', a variety of rice containing beta-carotene which is necessary for the synthesis of vitamin A. ${ }^{27}$ NGOs like Greenpeace have criticized the production of 'golden rice' as a waste of money and pleaded for fighting against vitamin A deficiency with conventional means (e.g. food supplements or home gardening projects). ${ }^{28}$ Many critics of agricultural biotechnology seem concerned that the 'golden rice' project may promote

.html; R. Schmid and C. Schmidt-Dannert, Biotechnology: An Illustrated Primer (Wiley-VCH, Weinheim 2016) 282.

22 M. Sears and J.D. Wolt, 'Ecological Considerations in Biotechnology: Ecological Concerns and Environmental Risks of Transgenic Crops' in: J.S. Popp, M.M. Jahn, M.D. Matlock and N.P. Kemper (eds), The Role of Biotechnology in a Sustainable Food Supply (CUP, Cambridge 2012) 141, 142-143.

${ }_{23}$ W.D. Hutchison et al., 'Areawide Suppression of European Corn Borer with Bt Maize Reaps Savings to Non-Bt Maize Growers' (2010) 330 Science 222.

24 See FDA, AquAdvantage Salmon [available online] https://www.fda .gov/AnimalVeterinary/DevelopmentApprovalProcess/GeneticEngineering/ GeneticallyEngineeredAnimals/ucm280853.htm.

25 ISAAA, ISAAA Brief 51 - 2015: Executive Summary [available online] http:// isaaa.org/resources/publications/briefs/51/executivesummary/default.asp.

26 European Commission, New Techniques in Agricultural Biotechnology, Scientific Advice Mechanism, Explanatory Note 02/2017 (28 April 2017) [available online] http://ec.europa.eu/research/sam/pdf/topics/explanatory_note_new_techniques agricultural_biotechnology.pdf, pp. 67-68.

27 For a more detailed analysis see P. Ronald, 'A Case Study of Rice from Traditional Breeding to Genomics: Rice - Food for the Gods' in: J.S. Popp, M.M. Jahn, M.D. Matlock and N.P. Kemper (eds), The Role of Biotechnology in a Sustainable Food Supply (CUP, Cambridge 2012) 180.

${ }_{28}$ Greenpeace, Golden Rice [available online] http://www.greenpeace.org/ international/en/campaigns/agriculture/problem/Greenpeace-and-Golden-Rice/. 
the broad acceptance of genetically engineered crops. 'Golden rice' thus became a crystallizing point in a broader and highly publicized controversy about transgenic crops. In June 2016, 107 Nobel laureates signed an open letter opposing the Greenpeace campaign:

WE CALL UPON GREENPEACE to cease and desist in its campaign against Golden Rice specifically, and crops and foods improved through biotechnology in general;

WE CALL UPON GOVERNMENTS OF THE WORLD to reject Greenpeace's campaign against Golden Rice specifically, and crops and foods improved through biotechnology in general; and to do everything in their power to oppose Greenpeace's actions and accelerate the access of farmers to all the tools of modern biology, especially seeds improved through biotechnology. Opposition based on emotion and dogma contradicted by data must be stopped.

How many poor people in the world must die before we consider this a 'crime against humanity'? ${ }^{29}$

This debate illustrates the ongoing fight between opponents and supporters of genetic engineering in the foods sector. The controversy focusses on the impact on health and environment, labelling of GM foods in the interest of consumer protection and the role of GM foods for nourishing a growing world population.

As to the risks for human health, the findings of science seem to be quite unambiguous on the topic of health risks:

The World Health Organization, the American Medical Association, the U.S. National Academy of Sciences, the British Royal Society, and every other respected organization that has examined the evidence has come to the same conclusion: consuming foods containing ingredients derived from GM crops is no riskier than consuming the same foods containing ingredients from crop plants modified by conventional plant improvement techniques. ${ }^{30}$

Still, public perception of green biotechnology is divided. The 2010 Eurobarometer survey on 'Europeans and Biotechnology' showed that 61 per cent of Europeans tend to disagree or totally disagree with GM foods as opposed to only 23 per cent tending to agree or totally agree with GM foods. ${ }^{31}$

29 Laureates Letter Supporting Precision Agriculture (GMOs) (29 June 2016) [available online] http://supportprecisionagriculture.org/nobel-laureate-gmo-letter_rjr .html. To date the letter has been supported by 123 laureates.

30 American Association for the Advancement of Science, Statement by the AAAS Board of Directors on Labelling of Genetically Modified Foods (20 October 2012) [available online] https://www.aaas.org/sites/default/files/AAAS_GM_statement.pdf.

31 G. Gaskell et al., Europeans and Biotechnology in 2010: Winds of Change? A Report to the European Commission's Directorate-General for Research (October 2010) 37. 
However, even within the European Union there are marked differences, as between the population of the United Kingdom ( 44 per cent supporters of green agriculture) and Greece (10 per cent supporters). ${ }^{32}$ The survey further indicates that perceptions often depend on the respective uses of genetic engineering. The introduction of resistance genes from another species into an apple (transgenesis) draws more criticism than the transfer of a gene that naturally exists in wild apples (cisgenesis). ${ }^{33}$

There is only modest awareness of the public that 'green biotechnology' covers far more than the engineering of genetically modified plants or animals for nutritional purposes. The bulk of the world's cotton production (80 per cent) is genetically modified. ${ }^{34}$ About 40 per cent of US corn production ( 85 per cent GM crops) serves to make ethanol for fuel. ${ }^{35}$

'Green biotechnology' has undergone a most dynamic development. In 2015 the cultivation of genetically modified plants covered an area of 179.7 million hectares. This signifies a more than 100-fold increase in the last 20 years. ${ }^{36}$ However, the strong presence of genetically modified crops is confined to a limited number of countries. The largest producers of genetically engineered crops are the United States (70.9 million ha) followed by Brazil (44.2 million ha) and Argentina (24.5 million ha). ${ }^{37}$ By contrast, in Europe only two countries grow biotech crops to a significant extent, with a total area of 0.1 million hectares. ${ }^{38}$

It may be expected that the new technology of genome editing (CRISPR/ Cas9, Talen, ZFN) will dramatically transform agricultural biotechnology. ${ }^{39}$ One example of genome editing is the development of a wheat variety which is resistant to mildew; another example is genetic dehorning of cattle in order to

32 ibid., 40.

33 ibid., 48-49.

34 Transparenz Gentechnik, Gentechnik-Pflanzen: Anbauflächen steigen 2017 weltweit auf 190 Millionen Hektar [available online] http://www.transgen.de/anbau/ 592.gentechnisch-veraenderte-pflanzen-anbauflaechen.html.

35 P. Ranum, J.P. Peña-Rosas and M.N. Garcia-Casal, 'Global Maize Production, Utilization, and Consumption' (2014) 1312 Annals of the New York Academy of Sciences 105.

36 ISAAA, ISAAA Brief 51 - 2015: Executive Summary [available online] http:// isaaa.org/resources/publications/briefs/51/executivesummary/default.asp.

37 ibid.

38 Transparenz Gentechnik, Gentechnik-Pflanzen: Anbauflächen steigen 2017 weltweit auf 190 Millionen Hektar [available online] http://www.transgen.de/anbau/ 592.gentechnisch-veraenderte-pflanzen-anbauflaechen.html.

39 Cf. European Commission, New Techniques in Agricultural Biotechnology, Scientific Advice Mechanism, Explanatory Note 02/2017 (28 April 2017) [available online] http://ec.europa.eu/research/sam/pdf/topics/explanatory_note_new_techniques _agricultural_biotechnology.pdf, pp. 56 et seq. 
pre-empt invasive physical dehorning. ${ }^{40}$ Hitherto, the inaccuracy of established genetic engineering presented an obstacle to the modification of polyploid organisms. With genome editing, Chinese scientists succeeded in simultaneously modifying the respective genes in all three sets of chromosomes of bread wheat. $^{41}$

The new technique of genome editing presents a challenge for the regulation of biotechnology. Genome editing allows the modification of DNA without transferring any foreign DNA to the target organism. As a consequence, the modified organism cannot be distinguished from any 'conventional' organism. ${ }^{42}$ In the absence of DNA transfer from other organisms, it would be difficult to justify heavy regulatory burdens on genome editing and products modified with this new technique. ${ }^{43}$ Synthetic biology is also a quickly evolving technique with great potential for the agricultural sector. ${ }^{44}$ This new technology may also benefit from being combined with gene editing.

\subsection{Biotechnology and health ('red' biotechnology)}

'Red' biotechnology is the application of biotechnological methods in the field of diagnostic and therapeutic medicine, pharmacology or health care. ${ }^{45}$ Biotechnology plays a vital role in the development of vaccines, other pharmaceuticals and antibodies as well as the production of hormones. It is used in human cell or gene therapy, provides new diagnostic methods and enhances the potential of personalized medicine. Pharmacogenomics explores the impact of genetic inheritance on the effect of drugs and medications on an individual.

40 D. Carroll and R.A. Charo, 'The Societal Opportunities and Challenges of Genome Editing' (2015) 16 Genome Biology 242; W. Tan et al., 'Precision Editing of Large Animal Genomes' (2012) 80 Advances in Genetics 37, Figure 7.

41 Y. Wang et al., 'Simultaneous Editing of Three Homoeoalleles in Hexaploid Bread Wheat Confers Heritable Resistance to Powdery Mildew' (2014) 32 Nature Biotechnology 947.

42 D. Carroll and R.A. Charo, 'The Societal Opportunities and Challenges of Genome Editing' (2015) 16 Genome Biology 242.

43 On the question whether from a regulatory point of view genome editing equates to 'classical' genetic engineering see Chapter 3, Section 4.3.

44 European Commission, New Techniques in Agricultural Biotechnology, Scientific Advice Mechanism, Explanatory Note 02/2017 (28 April 2017) [available online] http://ec.europa.eu/research/sam/pdf/topics/explanatory_note_new_techniques _agricultural_biotechnology.pdf, pp. 71 et seq.

45 L. Marks (ed.), Engineering Health: How Biotechnology Changed Medicine (Royal Society of Chemistry, Croydon 2018); J. Pongracz and M. Keen, Medical Biotechnology (Churchill Livingstone Elsevier, Amsterdam 2009); A. Sasson, Medical Biotechnology: Achievements, Prospects and Perceptions (United Nations University Press, Tokyo 2005). 
The use of modern biotechnological methods for therapeutic purposes reached new dimensions with the enormous progress in the science of genetics. In the early 2000 s, scientists succeeded in fully decoding the human genome. Human stem cell research and therapeutic cloning have opened new perspectives for treating diseases.

The techniques of genome editing are likely to bring a new dimension to biomedicine. ${ }^{46}$ Genome editing has been used to genetically modify human embryos created by IVF, yet without the intention to implant them into a woman. Genome editing also offers less controversial opportunities for medicine. Most recently, scientists successfully applied CRISPR/Cas9 to completely eliminate porcine endogenous retroviruses which are naturally embedded in a pig's DNA. Before, the potential of these viruses to infect human cells presented a serious obstacle for the therapeutic option of growing human transplant organs in pigs. ${ }^{47}$

On one side, biotechnology presents a broad spectrum for diagnosing and treating diseases. On the other side, many of these options have caused vehement controversies. Thus, the production and use of human stem cells and all forms of cloning have drawn ongoing criticism, which legislators in many countries translated into prohibitions or restraints. For many observers, the 'enhancement' of the human genome with all its possible implications is a virtually horrifying perspective. ${ }^{48}$ The potential of genome editing provoked an outcry among scientists, who demanded a moratorium or a ban on such research. ${ }^{49}$ Irrespective of the individual viewpoint, the potential of genome editing and other recently developed techniques confronts national and international regulation with new challenges.

For many years, abundant discussion has unfolded over gene therapy which purports to cure genetic diseases by transferring DNA into the patient's cells. Gene transfer is usually performed using a virus as a vector. The alteration of the human genome for therapeutic purposes is widely accepted in legal and ethical terms if the transfer does not affect the germ cells (somatic gene therapy). By contrast, germline gene therapy, that is the modification of germ

46 N. Savić and G. Schwank, 'Advances in Therapeutic CRISPR/Cas9 Genome Editing' (2016) 168 Translational Research 15; C. Liquan, A. Fisher, H. Huang and Z. Xie, 'CRISPR-Mediated Genome Editing and Human Diseases' (2016) 3 Genes \& Diseases 244.

47 'Gene editing to remove viruses brings transplant organs from pigs a step closer', The Guardian (10 August 2017) [available online] https://www.theguardian.com/ science/2017/aug/10/gene-editing-to-remove-viruses-brings-transplant-organs-from -pigs-a-step-closer.

48 Cf. J. Parrington, Redesigning Life: How Genome Editing Will Transform the World (OUP, Oxford 2016) 2.

49 ibid., 3-4. 
cells (sperm or egg cells), encounters strong opposition on moral grounds and legal restraints in many countries, especially in Europe. Intervention into the germline is often regarded as a violation of human dignity. However, it is by no means obvious why human dignity should ensure that even serious hereditary diseases will affect future generations (or why human dignity should prevent parents with hereditary diseases from having children). From a scientific perspective, the current inaccuracy of gene transfer and the related risks of causing unforeseeable heritable genetic errors still poses a major problem. ${ }^{50}$ This issue must be separated from principled objection on grounds of human dignity.

Gene editing may bring new options not only to somatic gene therapy, but also to germline therapy. In 2017 the American Society of Human Genetics approved a position statement on human germline genome editing, which was also endorsed by other societies for reproductive medicine or for genetics from other countries. ${ }^{51}$ This statement makes the following conclusions:

1. At this time, given the nature and number of unanswered scientific, ethical, and policy questions, it is inappropriate to perform germline gene editing that culminates in human pregnancy.

2. Currently, there is no reason to prohibit in vitro germline genome editing on human embryos and gametes, with appropriate oversight and consent from donors, to facilitate research on the possible future clinical applications of gene editing. There should be no prohibition on making public funds available to support this research.

3. Future clinical application of human germline genome editing should not proceed unless, at a minimum, there is (a) a compelling medical rationale, (b) an evidence base that supports its clinical use, (c) an ethical justification, and (d) a transparent public process to solicit and incorporate stakeholder input. ${ }^{52}$

A growing area in red biotechnology is the development of pluripotent stem cells. These pluripotent stem cells can evolve into any cell type and are a tool in regenerative medicine. ${ }^{53}$ In future, entire human organs might be grown from pluripotent stem cells. In light of the protection of unborn life and human dignity, the use of human embryos for the production of stem cells meets

50 The precision is increasing due to improved vectors, see L. Naldini, 'Gene Therapy Returns to Centre Stage' (2015) 526 Nature 351.

51 K.E. Ormond et al., 'Human Germline Genome Editing' (2017) 101 American Journal of Human Genetics 167.

52 K.E. Ormond et al., 'Human Germline Genome Editing' (2017) 101 American Journal of Human Genetics 167, 172-173.

53 See C. Mason and P. Dunnhill, 'A Brief Definition of Regenerative Medicine' (2008) 2 Regenerative Medicine 1. 
with strong opposition, notably in European countries. Thus, some Member States of the European Union prohibit the production of embryonic stem cells from embryos in vitro (with some allowing their importation), while EU law denies the patentability of inventions which involve embryonic stem cells. By contrast, production of and research with embryonic stem cells is allowed in the United Kingdom, the United States and many other countries. Stem cells can also be derived from cloned embryos, which are another subject of strong controversy.

Biotechnological techniques are not confined to therapy, but play an important role for diagnosis. Biological markers are analysed to diagnose diseases and detect risks. Prenatal screenings for chromosome abnormalities and mutations are consistent practice in contemporary medicine. Diagnosis and prevention can take place even earlier. In the case of IVF, preimplantation diagnosis of hereditary diseases is for many a method of choice ${ }^{54}$ Critics warn against the abuse of genetic profiling before the implantation of the embryos in vitro into the uterus for selection purposes ('eugenics'). To prevent undesirable genetic selections (e.g. as to sex or physical characteristics), preimplantation diagnosis is legally restricted or prohibited in many countries. In this context, it must be considered that many countries allow termination of pregnancy on the grounds of prenatal medical diagnosis. As the European Court of Human Rights held in Costa and Pavan v Italy, it would be inconsistent to deny preimplantation diagnostics as to a severe illness of which the parents are carriers or as a basis for the selection of embryos for implantation if existent legislation recognizes such genetic disposition as a criterion for prenatal screening and subsequent abortion. ${ }^{55}$

New and precise biotechnological diagnostic methods also permit medicine to be personalized in order to provide the patient with optimized therapy. While individualized medicine as such is not entirely new, advances in genetics, and not least the availability of big data, facilitate 'patient-tailored' treatments. ${ }^{56}$

\subsection{Reproductive medicine}

For a considerable time, biotechnology has played a major role in reproductive medicine. In particular, IVF allowed couples to overcome infertility or other barriers to natural conception. A major issue is the status and treatment of 'supernumerary' embryos in vitro which are not chosen for implantation. If not

54 Y. Verlinsky and A. Kuliev, Practical Preimplantation Genetic Diagnosis (Springer, Dordrecht 2005).

55 ECtHR, Costa and Pavan v Italy, Judgment, Application No. 54270/10 (28 August 2012) paras 64 et seq.

56 R. Hodson, 'Precision Medicine' (2016) 537 Nature 49. 
chosen, they are preserved for a period of time (through crypto-conservation), they may be used for the production of embryonic stem cells or will be otherwise 'disposed' of. This turns IVF into a legally and ethically disputed method of reproduction.

Even more controversial is the cloning of human beings, which some countries allow for therapeutic purposes (e.g. the therapy of the cloned patient or close relatives with stem cells or tissues which the patient's body will not reject). While States like the United Kingdom have adopted a rather liberal regime, many other countries (especially in continental Europe) have put a restrictive regime in place.

\subsection{Biotechnology in industrial processes ('white' biotechnology)}

'White' biotechnology stands for the use of biotechnology in industrial processes. ${ }^{57}$ White biotechnology operates with living cells and enzymes for industrial purposes. For a long time bacterial enzymes have been used in the processing of foods or as ingredients in washing powders. ${ }^{58}$ Biorefineries are facilities which convert biomass into marketable products (such as fuels and chemicals) and energy (power and heat). ${ }^{59}$ Biomass includes agricultural products as well as residues from households, industry and agriculture. ${ }^{60}$

White biotechnology may help in solving problems of energy supply which result from the finite availability of fossil energy resources. ${ }^{61}$ In economic terms, the production of biofuels is a particularly important application of white biotechnology. Biofuels can be mixed with gasoline or diesel and, therefore, are compatible with existing transportation technology and infrastructure. ${ }^{62}$ In the future, an important field of white biotechnology may be

57 G. Frazzetto, 'White Biotechnology' (2003) 4 EMBO Reports 835; R. Ulber and D. Sell (eds), White Biotechnology (Springer, Berlin 2007).

58 G. Frazzetto, 'White Biotechnology' (2003) 4 EMBO Reports 835, 835.

59 B. Kamm, P.R. Gruber and M. Kamm (eds), Biorefineries - Industrial Processes and Products: Status Quo and Future Directions (Wiley-VCH Verlag, Weinheim 2008); A. Pandey, R. Höfer, C. Larroche, M. Taherzadeh and K.M. Nampoothiri (eds), Industrial Biorefineries and White Biotechnology (Elsevier, Amsterdam 2015).

${ }^{60}$ E. de Jong and G. Jungmeier, 'Biorefinery Concepts in Comparison to Petrochemical Refineries' in: A. Pandey, R. Höfer, C. Larroche, M. Taherzadeh and K.M. Nampoothiri (eds), Industrial Biorefineries and White Biotechnology (Elsevier, Amsterdam 2015) 3, 6.

${ }_{61}$ R. Ulber and D. Sell (eds), White Biotechnology (Springer, Berlin 2007) IX.

62 E. de Jong and G. Jungmeier, 'Biorefinery Concepts in Comparison to Petrochemical Refineries' in: A. Pandey, R. Höfer, C. Larroche, M. Taherzadeh and K.M. Nampoothiri (eds), Industrial Biorefineries and White Biotechnology (Elsevier, Amsterdam 2015) 3, 7. 
the development of plastics which are not based on petroleum. An advantage of biotechnological production processes lies in the biodegradability of the products. ${ }^{63}$

As a technology which responds to the actual push for environmental sustainability, white biotechnology promises to be an expanding industrial sector. In 2015 the global white biotechnology market amounted to about 200 billion US dollars and is expected to reach about 490 billion US dollars by $2024 .{ }^{64}$ For the time being, fossil energy and fossil raw materials used for industrial production still have a considerable advantage over biotechnological energy and other raw materials. The potential of white biotechnology depends on when this gap will be closed. ${ }^{65}$

\subsection{Biotechnology and environmental protection ('grey' biotechnology)}

'Grey' biotechnology covers applications which serve environmental protection. Molecular and other forms of biotechnology provide techniques which assist in maintaining ecosystems and biodiversity, such as genetic analysis of populations and species or methods for genome storage. Another field of application related to the environment is the removal of contamination, e.g. the use of microorganisms to clean oil spills.

\subsection{Biotechnology and the exploitation of marine resources ('blue' biotechnology)}

'Blue' biotechnology encompasses the use of biotechnology for the exploitation of marine resources. Marine organisms are the source for regenerative and pharmaceutical agents as well as for marker molecules and enzymatically active molecules, which are used in medical diagnostics and research.

\footnotetext{
63 G. Frazzetto, 'White Biotechnology' (2003) 4 EMBO Reports 835, 835.

64 'White Biotechnology Market Analysis by Product, by Application and Segment Forecasts to 2024' PR Newswire (14 February 2017).

${ }_{65}$ For a comparison of costs see E. de Jong and G. Jungmeier, 'Biorefinery Concepts in Comparison to Petrochemical Refineries' in: A. Pandey, R. Höfer, C. Larroche, M. Taherzadeh and K.M. Nampoothiri (eds), Industrial Biorefineries and White Biotechnology (Elsevier, Amsterdam 2015) 3, 8.
} 


\section{BIBLIOGRAPHY}

Arora, S., R. Merchant and G.N. Allahbadia (eds), Reproductive Medicine: Challenges, Solutions and Breakthroughs (Jaypee Brothers Medical Publishers, New Delhi 2014)

Dederer, H.G. and M. Herdegen, Internationales Biotechnologierecht (C.F. Müller, Heidelberg 2017)

European Commission, New Techniques in Agricultural Biotechnology (Scientific Advice Mechanism, Explanatory Note 02, Brussels 2017) http: //ec.europa.eu/research/sam/pdf/topics/explanatory_note_new_techniques _agricultural_biotechnology.pdf

Fang, H.H.P. and T. Zhang, Anaerobic Biotechnology: Environmental Protection and Resource Recovery (Imperial College Press, London 2015)

Francioni, F. and T. Scovazzi (eds), Biotechnology and International Law (Hart Publishing, Oxford 2006)

Frazzetto, G., 'White Biotechnology' (2003) 4 EMBO reports 835

Herdegen, M., 'The International Regulation of Biotechnology' (Audiovisual Library of International Law) http://legal.un.org/avl/ls/Herdegen_HS.html

International Law Association, 'The Hague Conference (2010): International Law on Biotechnology’ (2010) 74 ILA Reports of Conferences 460

McVeigh, E., J. Guillebaud and R. Homburg (eds), Oxford Handbook of Reproductive Medicine and Family Planning (OUP, Oxford 2013)

Müller, W.E.G., H.C. Schröder and X. Wang (eds), Blue Biotechnology: From Gene to Bioactive Product (Springer, Berlin 2017)

Pandey, A., R. Höfer, C. Larroche, M. Taherzadeh and K.M. Nampoothiri (eds), Industrial Biorefineries and White Biotechnology (Elsevier, Amsterdam 2015)

Parrington, J., Redesigning Life: How Genome Editing Will Transform the World (OUP, Oxford 2016)

Pongracz, J. and M. Keen, Medical Biotechnology (Churchill Livingstone Elsevier, Amsterdam 2009)

Schmid, R. and C. Schmidt-Dannert, Biotechnology: An Illustrated Primer (Wiley-VCH, Weinheim 2016)

Smith, J.E., Biotechnology (CUP, Cambridge 2009)

Somsen, H. (ed.), The Regulatory Challenge of Biotechnology: Human Genetics, Food and Patents (Edward Elgar Publishing, Cheltenham 2007)

Ujang, Z. and M. Henze (eds), Environmental Biotechnology: Advancement in Water and Wastewater Application in the Tropics (IWA Publishing, London 2004)

Ulber, R. and D. Sell (eds), White Biotechnology (Springer, Berlin 2007) 